doi: 10.17492/pragati.v3i2.7746

\title{
Interaction between Monetary and Fiscal Policy: Empirical Evidence from India
}

\author{
Arundhati Mallick* and Narayan Sethi**
}

\begin{abstract}
Monetary policy and fiscal policy have their own perspective towards maintaining economic stability of the country. However, for a well-functioning economy, they need to work in coordination with each other. In this paper we are empirically examining the interaction between monetary and fiscal policy by using Vector Error Correction Model (VECM) for the period of April 2010 to March 2015. The study also discusses game theoretic approach to know about the strategic interaction between monetary and fiscal policy. The study uses change in gross fiscal deficit and output to represent fiscal policy and inflation and interest rate to represent the monetary policy. The results indicate that fiscal policy responds well to any changes in monetary policy but reverse is not taking place.
\end{abstract}

Keywords: Monetary policy, Fiscal policy, Vector Error Correction Model (VECM)..

\subsection{Introduction}

Monetary policy and fiscal policy are two important pillars of an economy to maintain the economic stability of any country. Both the policies have different objectives and different perspectives towards maintaining economic stability. Monetary policy is more inclined towards maintaining price stability while fiscal policy is more inclined towards maintaining growth and employment level of the economy. According to Philips curve, a high level of employment or output is possible to achieve with a higher level of inflation. But this works only in short run, in long run there is no trade-off between inflation and employment. Monetary policy plays an active role in the long run.

*Research Scholar, Deptt. of Humanities and Social Sciences, National Institute of Technology (NIT) Rourkela, Odisha (email: arundhatimallick42@gmail.com)

**Assistant Professor in Economics, Deptt. of Humanities and Social Sciences, National Institute of Technology (NIT) Rourkela, Odisha (email: nsethinarayan@gmail.com) 
2 | PRAGATI: Journal of Indian Economy, Volume 3, Issue 2

With the passage of time policies are changing, and many countries declare themselves as inflation targeting countries. In that case they strictly follow the objective of price stability, which is the main objective of monetary policy. By this, we get a general idea that the role of fiscal policy becomes minimal. However, in reality to achieve the price stability in the economy we also need the cooperation from fiscal policy. It is well known that monetary policy operates with a lag. In that case monetary policy needs cooperation from fiscal policy to implement its policies. Fiscal policy needs to increase the fiscal tax to satisfy the condition of budget equilibrium. Fiscal policy acts as a follower to monetary policy. This is the scenario of Ricardian regime. In this regime monetary policy acts as active policy and fiscal policy act as passive policy. An active policy considers the expected future behaviour of economic variables while a passive policy considers the present and past behaviour of economic variables. Any lack of coordination between these polices adversely affects the overall economic situation of a country. This reduces the credibility of the policies and which ultimately decreases their effectiveness. Similarly, fiscal policy also needs the cooperation from monetary policy. Central banks often require financing public sector deficits, including those arising from quasi fiscal activities.

There are some problems in attaining the coordination between monetary and fiscal policy. The first is that of time frame. Both policies act in different time periods and operate with different time lags. Second, what will be the main objective if both policies work cooperatively? How economic variables representing fiscal policy respond to monetary policy and variables representing monetary policy respond to fiscal policy actions? So the main focus of our study is to find out how different macroeconomic variables response to different policies adopted by monetary and fiscal authorities. We also analyse the strategic interaction between monetary and fiscal policy by using game of prisoner's dilemma and battle of sexes.

This paper is organised into six sections. Section 1 has introduced the topic. Section 2 represents the game theory approach and section 3 discusses some earlier literature. Section 4 highlights the data and methodology used in the study. Section 5 discusses the empirical results and section six draws the conclusion.

\subsection{Game Theory Approach}

Monetary authority and fiscal authority interact to maintain stable economy by targeting different economic agents. According to Philips curve, an economy can achieve a full employment equilibrium by rising inflation in the economy. However, this will be a temporary phenomenon and rising inflation will ultimately harm the economy. 
Therefore, a proper coordination is required between fiscal and monetary policy to achieve equilibrium in the economy. This interaction can be presented in a game theory technique and we can then find out an optimal solution to this.

Table 1 represents the payoff matrix between monetary policy and fiscal policy by using $2 \times 2$ game theoretic representation of prisoner's dilemma. From given possible outcomes non-cooperation from both the polices (i.e. $(\mathrm{d}, 4)$ payoff) is only possible in one case and the outcome of Nash equilibrium is high inflation, low employment and low output.

Table 1: Payoff Matrix for Prisoner's Dilemma

\begin{tabular}{|c|c|c|c|}
\hline & \multicolumn{3}{|c|}{ Fiscal Policy } \\
\hline \multirow{4}{*}{ Monetary } & & Cooperation & Non-cooperation \\
\cline { 2 - 4 } Policy & \multirow{3}{*}{ Cooperation } & Low Inflation & Low Inflation \\
\cline { 2 - 4 } & & High Employment & Low Employment \\
& & High Output & Low output \\
& & $(\mathrm{a}, 1)$ & $(\mathrm{b}, 2)$ \\
& Non- & High Inflation & High Inflation \\
& cooperation & High Employment & Low Employment \\
& & High Output & Low Output \\
& & $(\mathrm{c}, 3)$ & $(\mathrm{d}, 4)$ \\
\hline
\end{tabular}

While payoff $(\mathrm{a}, 1)$ is pareto superior solution with low inflation, high employment and high output. So cooperation between both the policies is needed to have a stable and better economy. According to Philips curve, a high level of employment is possible at the cost of high inflation, which is our Nash equilibrium. However, the problem is inflation up to threshold level is good, either it does not affect the growth of the economy or positively affects it. Beyond that, it starts affecting the economy negatively. So Nash equilibrium here is not a real practical solution.

If we go for an active or inactive monetary or fiscal policy, then the payoff matrix would be as given in Table 2. Table 2 represents the payoff matrix between monetary policy and fiscal policy by using $2 \times 2$ game theory representation of battle of sexes. From given possible outcomes, payoff of $(c, 3)$ and $(b, 4)$ are two possible Nash equilibria. For fiscal policy payoff $(c, 3)$ of high inflation, high employment and high output will be the preferred Nash, while for monetary policy payoff $(b, 2)$ of low inflation, low employment and low output will be preferred Nash. 
4 | PRAGATI: Journal of Indian Economy, Volume 3, Issue 2

Table 2: Payoff Matrix for Battle of Sexes

\begin{tabular}{|c|c|c|c|}
\hline & \multicolumn{3}{|c|}{ Fiscal Policy } \\
\hline \multirow{4}{*}{$\begin{array}{c}\text { Monetary } \\
\text { Policy }\end{array}$} & \multirow{3}{*}{ Passive } & Active & Passive \\
\cline { 2 - 4 } & & High Inflation & High Inflation \\
& & High Employment & Low Employment \\
& & $(\mathrm{c}, 3)$ & Low Output \\
& & Low Inflation & (d,4) \\
& \multirow{4}{*}{ Active } & High Employment High & Low Employment \\
& & Output & Low output \\
& & $(\mathrm{a}, 1)$ & $(\mathrm{b}, 2)$ \\
\hline
\end{tabular}

\subsection{Review of Literature}

Leith \& Wren-Lewis (2000) state that when monetary policy anchors real interest rate to manage inflation, then a self-stabilising fiscal policy is required to ensure model stability. A fiscal policy which does not, by itself, ensure fiscal solvency constraints monetary policy to be relatively passive. According to Friedman (1948), a stable framework of monetary and fiscal policy can eliminate the uncertainty and undesirable political implications of discretionary action by governmental authorities. Woodford (2001) also argues that to maintain price stability both appropriate monetary and fiscal policy is required.

Aktas, Kaya \& Özlale (2010) study the coordination between monetary and fiscal policy especially for an inflation targeting emerging market. The study takes Turkish economy as laboratory for the study and finds that dynamics in fiscal policies plays a very important role in effective implementation of the monetary policies. Bertella et al. (2015) examine the interaction between fiscal and monetary policy in a dynamic non-linear model. The paper separately studies the interaction between two policies for inflation targeting and growth targeting economy. As a result, they find that stable equilibrium is more restrictive in inflation targeting economy than growth targeting economy. Sufficient conditions of maintain stable equilibrium in growth targeting economy are not sufficient for inflation targeting economy.

Raj, Khundrakpam \& Das (2011) also empirically study the interaction of monetary and fiscal policy for India from the period of 2000Q2 to 2010Q1 by using quarterly data of inflation rate (WPI), change in gross fiscal deficit, policy rate and output gap. As a result, they find that reaction of monetary and fiscal policies to any 
shocks in inflation and output are opposite. Fiscal policy reacts in a pro-cyclical way while monetary policy reacts in a counter-cyclical way. The study suggests that fiscal policy is effective in increasing the level of output in short run and decreases the level of saving and investment in the medium term. Similarly, Kuncoro \& Sebayang (2013) try to find out the dynamic interaction between monetary and fiscal policies for Indonesia from the period of 1999-2010. The study finds interest rate and primary balance surplus to be the main determinants of interaction between both the policies and monetary policy to be more dominant than fiscal policy in case of India. Moreira, Soares, Sachsida, \& Loureiro (2011) empirically analyse the interaction between monetary and fiscal policies in case of Brazil from the period of 1995:Q1 to 2008:Q3 and especially focus on whether fiscal policies are active or passive in this time span. The study gets quite confusing result. According to Lepper model, fiscal policy was active and monetary policy was active, while in case of Ricardian regime monetary policy was active and fiscal policy was passive but again in case of non-Ricardian regime fiscal policy was active and monetary policy was passive.

Canzoneri, Cumby, \& Diba (2010) discusses about different theories related to the optimal policy of the economy. The study focuses to know best combination of monetary and fiscal policies to stabilise the economy by looking at both positive and normative aspects of interaction between monetary and fiscal policy. Goyal (2002) argues about rules related to coordinate monetary and fiscal policies. The study suggests following a fiscal responsibility act, which focus on back loaded reduction of the revenue deficit while protecting capital expenditures, automatic stabilization and incorporating escape clauses. This is also known as fiscal deficit Zone targeting and can make the coordination between monetary and fiscal policies.

Laurens \& Piedra (1998) study recent discourses in coordination of monetary and fiscal policies. Nowadays the main objective of monetary policy is to ensure price stability and fiscal policy is to manage public debt. In this case managing the coordination between two policies is quite difficult. The study suggests that central banks must have full control over overall liquidity developments in the economy and its ability influence them by means of its discretionary monetary operations. Afonso \& Balhote (2014) try to examine the interaction between monetary and fiscal policies for 14 EU countries using panel data from the period of 1970 to 2012 but the study do not get any evidence related to Central bank's response to fiscal policy.

\subsection{Data and Methodology}

To study the interaction between monetary and fiscal policy we take monthly data of change in four variables, i.e., gross fiscal deficit (GFD), output gap inflation and interest 
6 | PRAGATI: Journal of Indian Economy, Volume 3, Issue 2

rate from the period of April 2010 to March 2015. GFD and output gap will represent the fiscal policy while inflation and interest will represent the monetary policy. These two policies have their own objectives. Since monetary policy's main objective is to maintain the price stability, so to represent that we have taken inflation. On the other hand, fiscal policy objective is to maintain growth rate and give special preference to lower the unemployment level. To represent this, we take output gap as proxy to represent the unemployment level. Again as monthly data of Gross Domestic Product (GDP) to represent output is not available, we take Index of Industrial Production (IIP) as proxy to GDP, then calculate output gap from IIP by using Hodrick-Presscot Filter.

Generally, the HP filter is used to extract cyclical movements in time series. The function of the HP filter based on the assumption that the non-stationary movements in time series are captured by both smooth and slowly changing trends. Suppose the series $\left(x_{t}\right)$ is composed of the trend component $\left(g_{t}\right)$ and cyclical component $\left(c_{t}\right)$.

$$
x_{t}=g_{t}+c_{t}
$$

Then HP filter isolates the cyclical component by minimising.

$$
\sum_{t-1}^{T}\left(x_{t} g_{t}\right)^{2}+\lambda \sum_{t-2}^{T-1}\left[\left(g_{t+1}-g_{t}\right)-\left(g_{t}-g_{t-1}\right)\right]^{2}
$$

This cyclical component represents the output gap. We have also taken change in GFD to represent the fiscal policy. Interest also has been taken to represent monetary policy as monetary policy use interest rate as an instrument to manage its objective of maintaining price stability in the economy.

Then we use Vector Error Correction Model (VECM) to empirically study the coordination between monetary and fiscal policy. VECM can be expressed as

$$
\Delta Y_{t}=\Gamma_{1} \Delta Y_{t-1}+\Gamma_{2} \Delta Y_{t-2}+\cdots+\Gamma_{k-1} \Delta Y_{t-k}+\Pi Y_{t-k} \varepsilon_{t}
$$

where $\Delta$ is the rank difference operator:

$$
\Gamma_{1}=-\mathrm{I}-\Pi_{1}-\cdots-\Pi_{i}, \quad i=1,2, \ldots, k
$$

\subsection{Empirical Results}

Before starting the analysis, we tested the stationarity of the variables. GFD, inflation and output gap are stationary at level, while interest rate is stationary at first difference according to Augmented Dickey Fuller (ADF) test (Table 3). Then we test for co-integrating relationship between variables by using Johansen Jusillius test (Table 4) and according to maximum eigen values, there are two co-integrating vectors that exist between variables. Therefore, we go for VECM model instead of VAR. Then we analyse 
both variance decomposition (Table 5) and impulse response function (IRF) obtained from a shock of one standard deviation.

Table 3: Results of Unit Root Test without Trend

\begin{tabular}{|l|l|l|}
\hline \multicolumn{2}{|c|}{ Variables } & \multicolumn{1}{|l|}{ Augmented Dickey Fuller } \\
\cline { 2 - 3 } & t-statistics At Level & P Value \\
\hline \multicolumn{2}{|c|}{} \\
\hline Gross Fiscal Deficit & -7.80 & 0.00 \\
\hline Output Gap & -7.80 & 0.00 \\
\hline Inflation & -1.37 & 0.99 \\
\hline Interest Rate & -1.69 & 0.42 \\
\hline \multicolumn{2}{|c|}{$\mathbf{1}^{\text {st }}$ Difference } & 0.00 \\
\hline Gross Fiscal Deficit & $-9.73 \quad 0.00$ \\
\hline Output Gap & -10.65 & 0.00 \\
\hline Inflation & -5.59 & 0.00 \\
\hline Interest Rate & -7.25 & \\
\hline
\end{tabular}

*The tabulated value at $5 \%$ level of significance is -3.42 .

Table 4: Result of Johansen Co integration Test

\begin{tabular}{|c|c|c|c|c|}
\hline $\begin{array}{c}\text { Hypothesized } \\
\text { No. of CE(s) }\end{array}$ & Eigen value & Trace Statistic & 0.05 Critical Value & Prob.** $^{*}$ \\
\hline None* $^{*}$ & 0.46 & 70.38 & 47.85 & 0.00 \\
\hline At most 1 & 0.39 & 34.07 & 29.79 & 0.01 \\
\hline At most 2 & 0.07 & 4.54 & 15.49 & 0.85 \\
\hline At most 3 & 0.00 & 0.18 & 3.84 & 0.66 \\
\hline
\end{tabular}

Null hypothesis indicates no co integration at the 0.05 level.

*denotes rejection of the hypothesis at the 0.05 level.

\section{Responses of Gross Fiscal Deficit}

Figure 1 shows the responses of GFD to any shocks to other variables. Any shock to other variables has negative effect on GFD. In case of inflation, output gap and GFD itself has immediate negative impact on GFD but in case of shocks to interest rate GFD takes some lag to response. All the effects become normal by $4^{\text {th }}$ period. 
8 | PRAGATI: Journal of Indian Economy, Volume 3, Issue 2

Table 5: Variance Decomposition of Variables

\begin{tabular}{|c|c|c|c|c|}
\hline \multicolumn{5}{|c|}{ Variance Decomposition of GFD } \\
\hline Period & GFD & Output Gap & Inflation & Interest rate \\
\hline $\mathbf{1}$ & 100.0000 & 0.000000 & 0.000000 & 0.000000 \\
\hline $\mathbf{2}$ & 95.97694 & 1.235904 & 2.586949 & 0.200203 \\
\hline $\mathbf{3}$ & 83.65930 & 1.408625 & 7.864722 & 7.067350 \\
\hline $\mathbf{4}$ & 80.49315 & 4.373087 & 8.309818 & 6.823946 \\
\hline $\mathbf{5}$ & 79.94385 & 4.371161 & 8.715840 & 6.969151 \\
\hline $\mathbf{7}$ Variance Decomposition of Output Gap \\
\hline $\mathbf{1}$ & 1.059099 & 98.94090 & 0.000000 & 0.000000 \\
\hline $\mathbf{3}$ & 2.414919 & 88.39265 & 1.393187 & 7.799239 \\
\hline $\mathbf{4}$ & 8.113093 & 79.46451 & 2.293439 & 10.12895 \\
\hline $\mathbf{5}$ & 9.136892 & 78.51089 & 2.480332 & 9.871882 \\
\hline $\mathbf{1}$ & 8.780041 & 75.50246 & 3.037751 & 12.67974 \\
\hline $\mathbf{2}$ & 0.043849 & 0.900442 & 99.05571 & 0.000000 \\
\hline $\mathbf{3}$ & 0.048211 & 1.835922 & 96.80632 & 1.309545 \\
\hline $\mathbf{4}$ & 0.410806 & 1.624371 & 96.21347 & 1.751353 \\
\hline $\mathbf{5}$ & 0.405327 & 1.719565 & 95.98948 & 1.885629 \\
\hline $\mathbf{1}$ & 0.358517 & 1.709843 & 95.87402 & 2.057619 \\
\hline $\mathbf{2}$ & 0.023721 & 1.240407 & 3.972774 & 94.76310 \\
\hline $\mathbf{3}$ & 0.648364 & 1.099544 & 5.000583 & 93.25151 \\
\hline $\mathbf{4}$ & 0.467762 & 2.645401 & 3.700819 & 93.18602 \\
\hline $\mathbf{5}$ & 0.453149 & 2.126647 & 4.330616 & 93.08959 \\
\hline
\end{tabular}

Cholesky Ordering: GFD, Output Gap, Inflation, Interest Rate.

\section{Responses of Inflation}

Figure 2 represents the response of inflation to, shocks to other variables. From the above figure we can clearly see that inflation highly react to any shocks to inflation itself and interest rate. It does not significantly respond to any shocks to GFD or output gap.

\section{Responses of Output Gap}

Figure 3 shows the response of output gap in case of any shocks to other variables. Output gap responds positively to the shocks to GFD while it responds negatively to the interest rate. In any case, shock to inflation output gap takes some time lag to respond negatively. May be on initial stages inflation affects output positively, but when inflation increases beyond threshold level it affects output negatively. 
Interaction between Monetary and Fiscal Policy: Empirical Evidence from India | 9
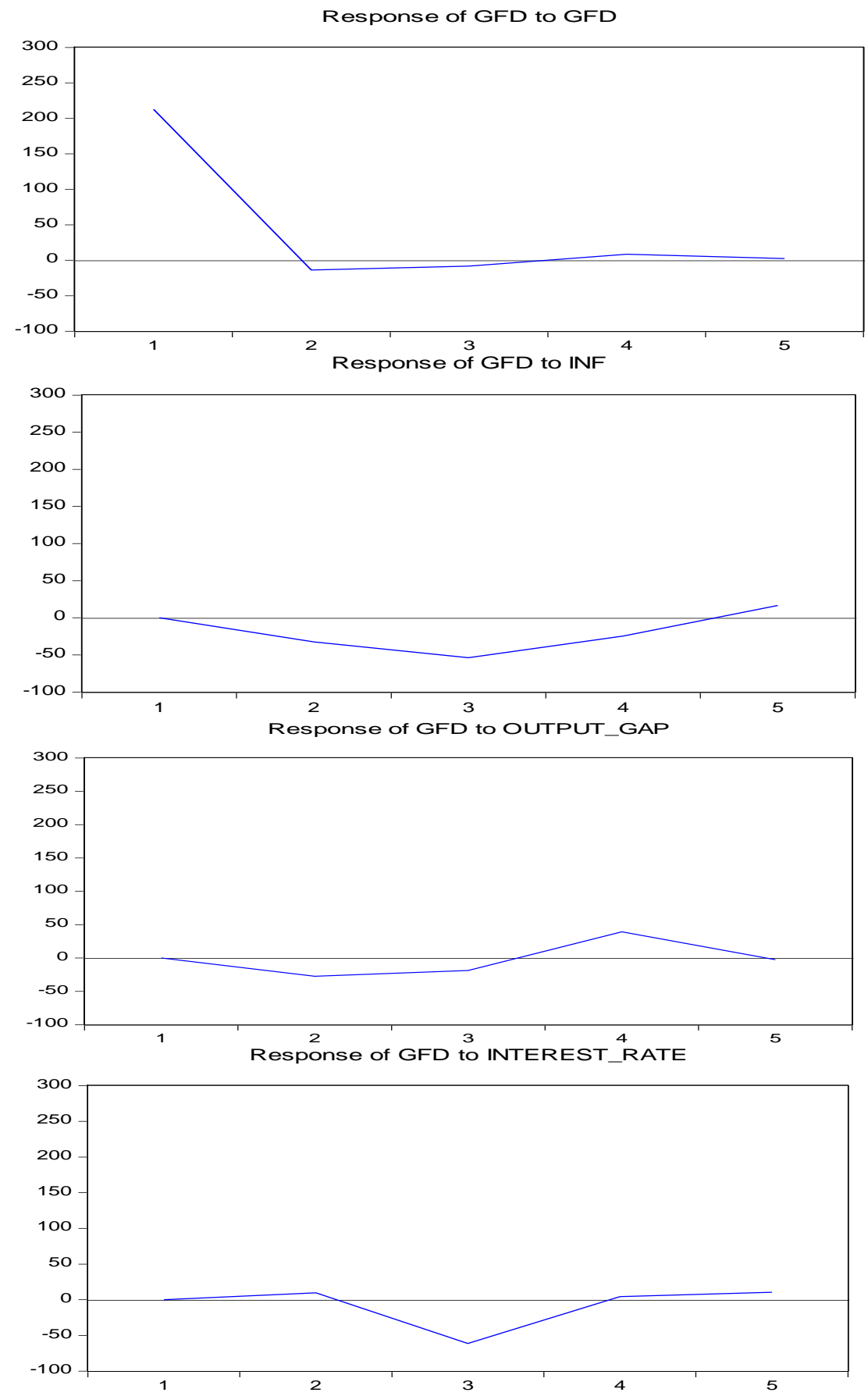

Figure 1: Responses of Gross Fiscal Deficit 
10 | PRAGATI: Journal of Indian Economy, Volume 3, Issue 2

Response of INF to GFD
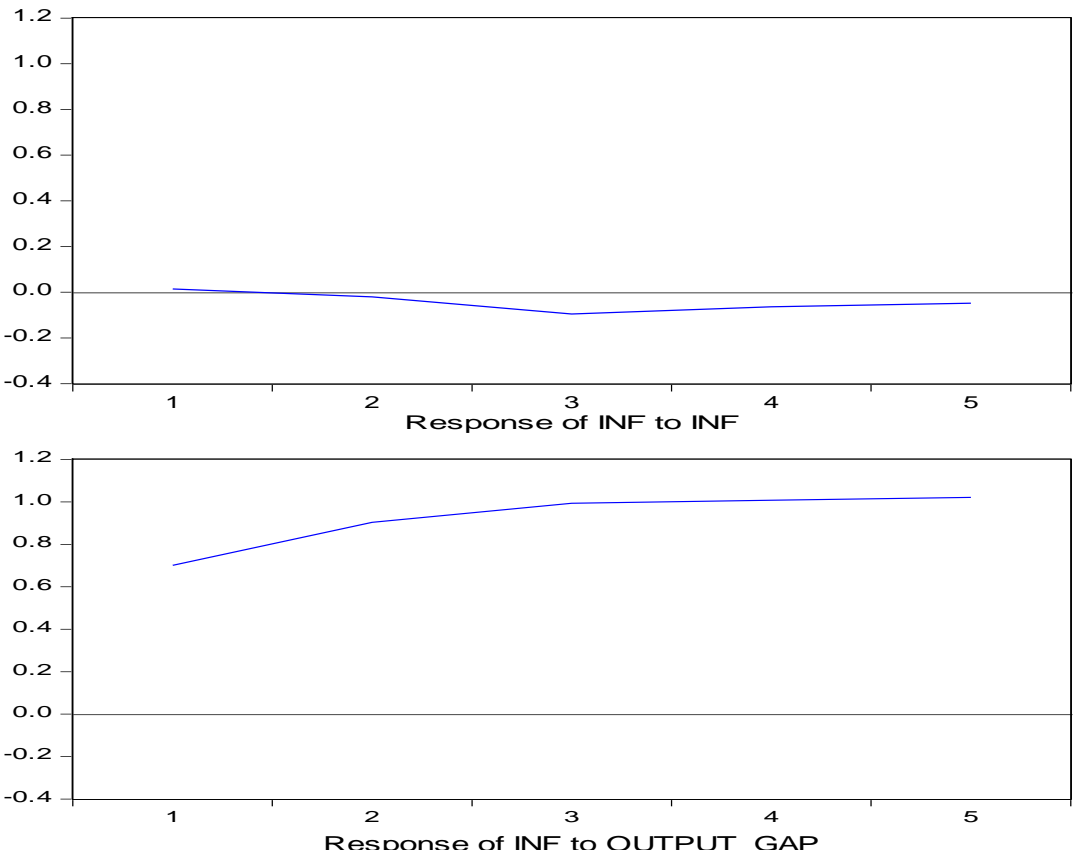

Response of INF to OUTPUT GAP
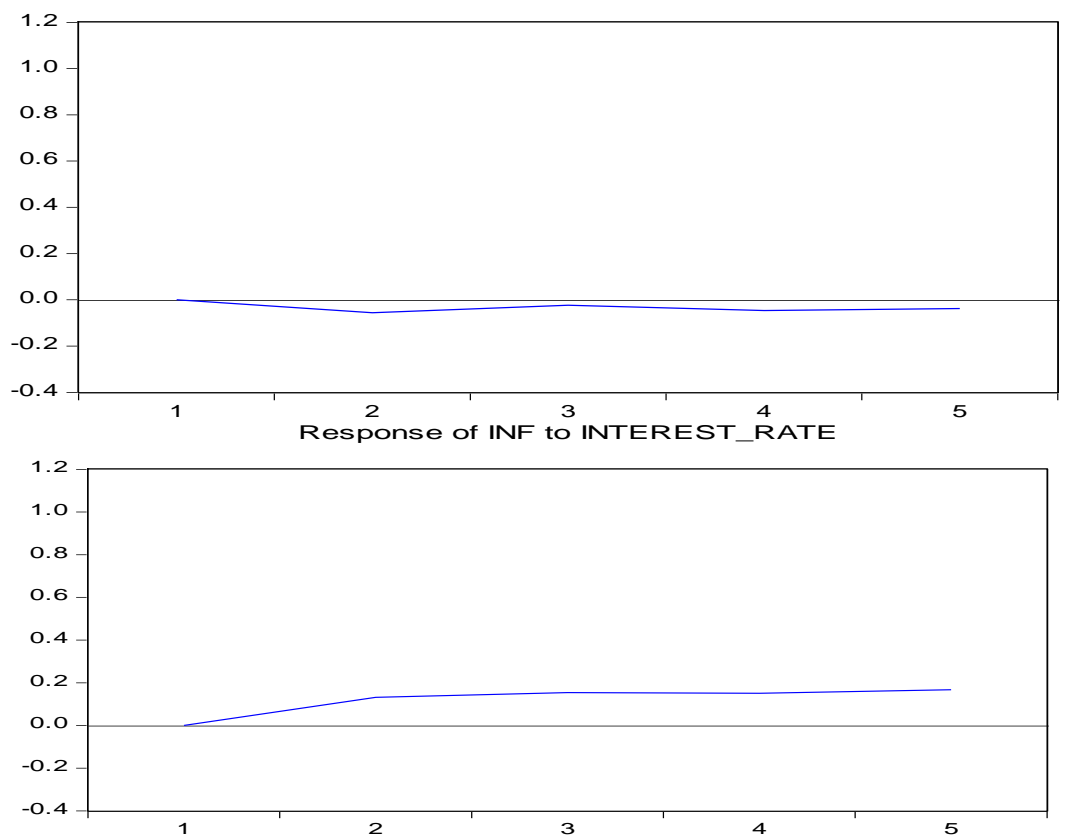

Figure 2: Responses of Inflation 
Interaction between Monetary and Fiscal Policy: Empirical Evidence from India

Response of OUTPUT_GAP to GFD
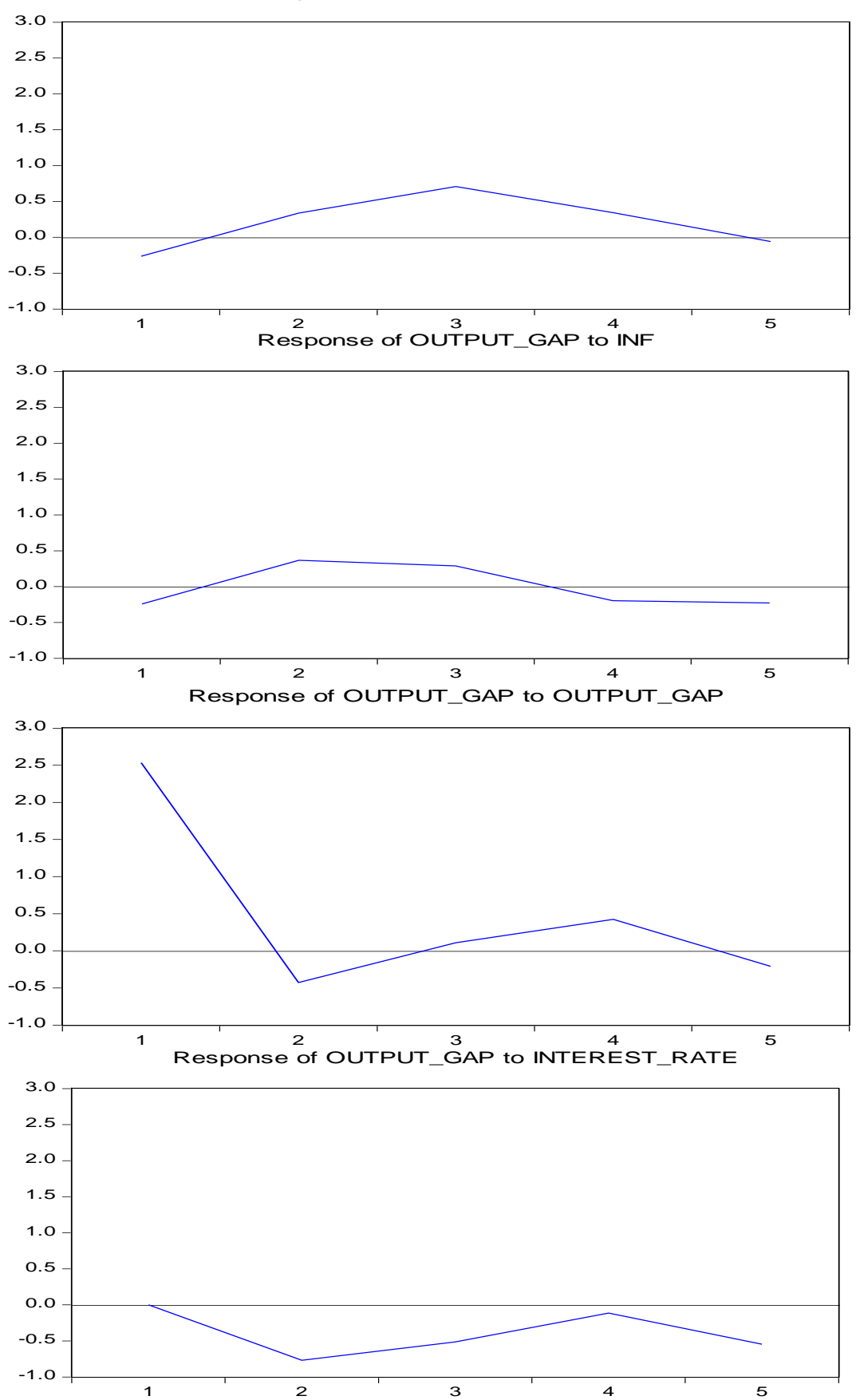

Figure 3: Responses of Output Gap 
12 | PRAGATI: Journal of Indian Economy, Volume 3, Issue 2

Response of INTEREST RATE to GFD

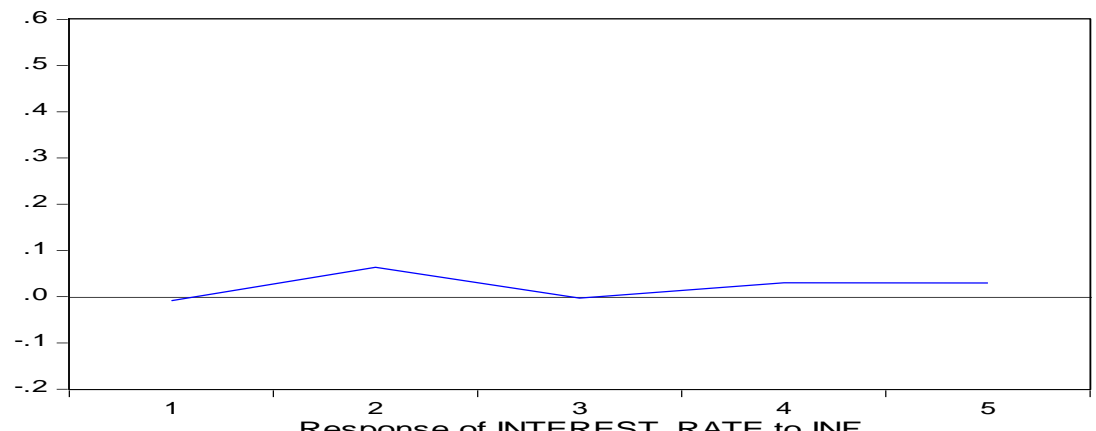

Response of INTEREST RATE to INF
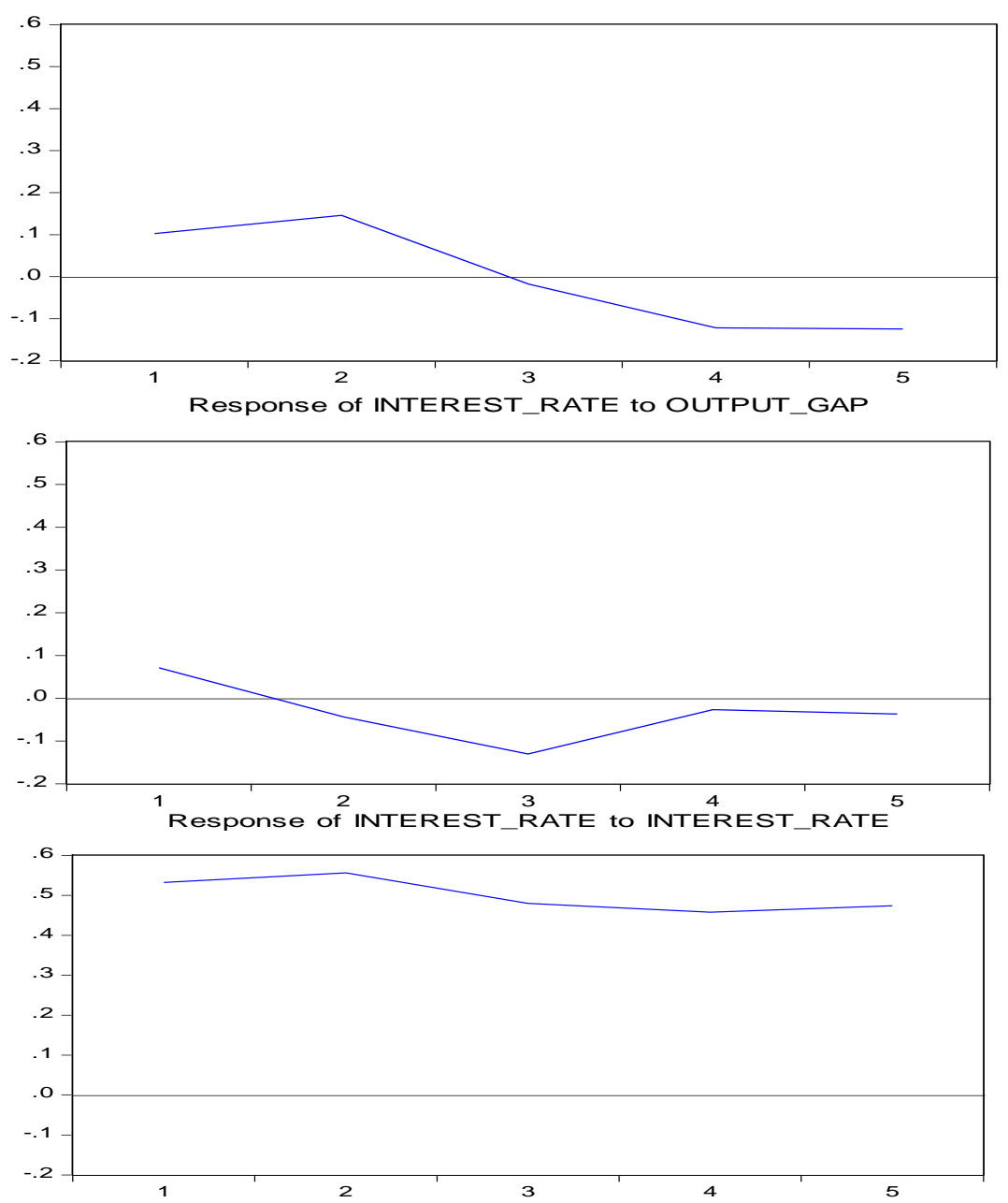

Figure 4: Responses of Interest Rate 


\section{Responses of Interest Rate}

Figure 4 represents the response of interest rate to the shocks of other variables. Any shock to GFD does not affect much to interest rate but when any shock is given to output gap, interest rate responds negatively and after some time it start to recover but still remains negative. Interest rate takes some time in reacting to any shock to inflation but after that it shows a sudden fall.

Overall we can clearly see that the variables representing fiscal policy are reacting to any shock to variables representing monetary policy but reverse is not happening. Variables representing monetary policy are not much responsive to any shock that takes place in variables representing fiscal policy. As already discussed, to maintain the objective of price stability by monetary policy, there is a need for cooperation of fiscal policy which is taking place but vice versa is not taking place. Variance decomposition represented in Table 5 also shows the same thing. The final objective of both the policies is to have stable economy although they have different objectives; sometimes they deviate from achieving their final objective. This can be seen from Figure 5 below. Residual of output gap represent the deviation from the side of fiscal policy while residual from inflation represents the deviation from the side of monetary policy. Figure 5 shows that fiscal policy needs more time lag than monetary policy. Monetary policy actions are quicker than fiscal policies. The question that invariably arises is that between monetary and fiscal policy, who will be the first one to takes initiatives if any deviation takes place in the economy. They both decide different combinations of their nominal anchors to mane the economic instability. This may work sometimes while not at other times.

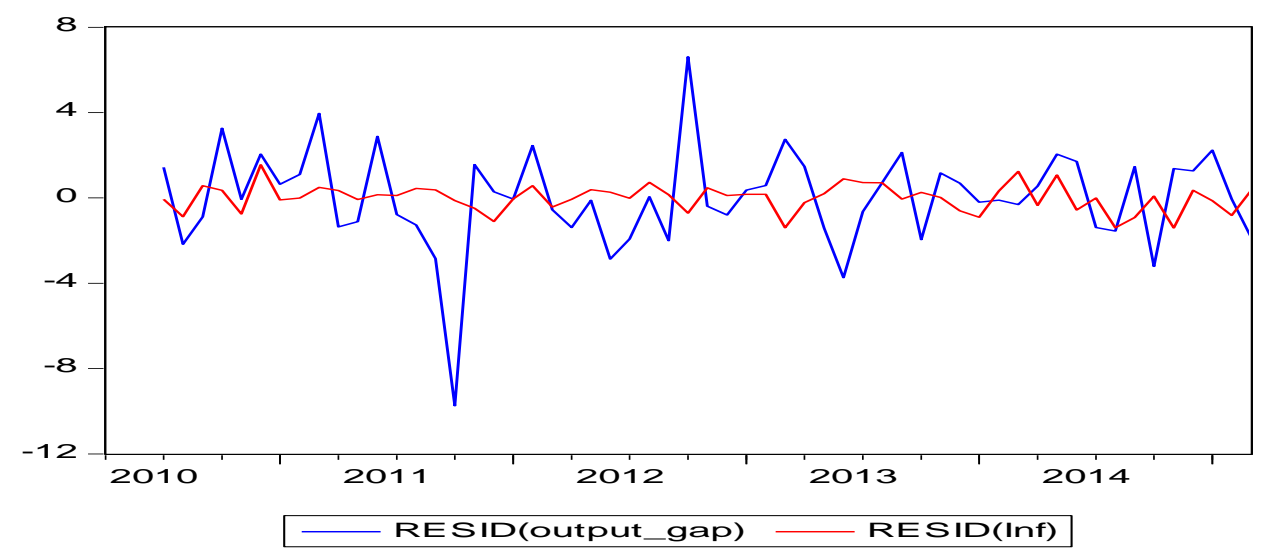

Figure 5: Deviation of Monetary and Fiscal Policy 
14 | PRAGATI: Journal of Indian Economy, Volume 3, Issue 2

\subsection{Conclusion}

This study analyses the interaction between monetary and fiscal policy for India. The coordination between monetary and fiscal policy is a sufficient condition to achieve the financial stability in the economy. We find that a good response from fiscal policy leads to changes that take place from the action of monetary policy. However, monetary policy is less responsive to changes arising out of fiscal policy.

\section{References}

Afonso, A., \& Balhote, R. (2014). Interactions between Monetary Policy (No. WP13/2014/DE/UECE). Lisbon.

Aktas, Z., Kaya, N., \& Özlale, Ü. (2010). Coordination between monetary policy and fiscal policy for an inflation targeting emerging market. Journal of International Money and Finance, 29(1), 123-138. doi:10.1016/j.jimonfin.2009.07.008

Bertella, M. a., Rego, H. a., Neris, C., Silva, J. N., Podobnik, B., \& Stanley, H. E. (2015). Interaction between Fiscal and Monetary Policy in a Dynamic Nonlinear Model. Plos One, 10(3), e0118917. doi:10.1371/journal.pone.0118917

Canzoneri, M., Cumby, R., \& Diba, B. (2010). The Interaction Between Monetary and Fiscal Policy. In Handbook Of Monetary Economics (1st ed., Vol. 3, pp. 935-999). Elsevier B.V. doi:10.1016/B978-0-444-53454-5.00005-0

Friedman, M. (1948). A monetary and fiscal framework for economic stability. The American Economic Review, 38(3), 245-264.

Goyal, A. (2002). Coordinating Monetary and Fiscal Policies : A Role for Rules? In K. S. Parikh \& R. Radhakrishna (Eds.), India Development Report. New Delhi: IGIDR and Oxford University Press.

Kuncoro, H., \& Sebayang, K. (2013). The dynamic interaction between monetary and fiscal policies in Indonesia. Romanian Journal of Fiscal Policy, 4(1), 47-66.

Laurens, B., \& Piedra, E. D. La. (1998). Coordination of monetary and fiscal policies (No. WP/98/25). Retrieved from

http://papers.ssrn.com/sol3/papers.cfm?abstract_id=882258 
Leith, C., \& Wren-Lewis, S. (2000). Interactions between monetary and fiscal policy rules. The Economic Journal, 110(462), C93-C108.

Moreira, T. B. S., Soares, F. A. R., Sachsida, A., \& Loureiro, P. R. A. (2011). The interaction of monetary and fiscal policy: The Brazilian case. Modern Economy, 02(02), 114-123. doi:10.4236/me.2011.22016

Raj, J., Khundrakpam, J. K., \& Das, D. (2011). An Empirical Analysis of Monetary and Fiscal Policy Interaction in India (No. 15/2011).

Woodford, M. (2001). Fiscal requirements for price stability. Journal of Money, Credit and Banking, 33(3), 669-728. doi:10.2307/2673890 